Article

\title{
Destoning the Moatize Coal Seam, Mozambique, by Dry Jigging
}

\author{
Carlos Hoffmann Sampaio 1,*, Weslei Monteiro Ambrós ${ }^{2}$, Bogdan Cazacliu ${ }^{3}$, \\ Josep Oliva Moncunill ${ }^{1}$, David Selemane José ${ }^{4}$, Gerson Luis Miltzarek ${ }^{2}$, \\ Irineu Antônio Schadach de Brum ${ }^{2}$, Carlos Otávio Petter ${ }^{2}$, Eunírio Zanetti Fernandes ${ }^{5}$ and \\ Luis Felipe Silva Oliveira ${ }^{6}$
}

1 Departament d'Enginyeria Minera, Industrial i TIC (EMIT), Escola Politècnica Superior d'Enginyeria de Manresa (EPSEM), Universitat Politècnica de Catalunya (UPC), Av. Bases de Manresa 61-63, 08242 Manresa, Spain; josep.oliva@upc.edu

2 Mineral Processing Laboratory, Federal University of Rio Grande do Sul, 9500 Bento Gonçalves Avenue, Porto Alegre 91501-970, Brazil; weslei.ambros@ufrgs.br (W.M.A.); gerson.miltzarek@ufrgs.br (G.L.M.); irineu.brum@ufrgs.br (I.A.S.d.B.); cpetter@ufrgs.br (C.O.P.)

3 Gustave Eiffel University, Aggregates and Materials Processing Laboratory, Route de Bouaye-CS4, CEDEX 44344 Bouguenais, Nantes, France; bogdan.cazacliu@ifsttar.fr

4 Instituto Supeior Politécnico de Tete, km 1, EN7 Matundo, Tete, Mozambique; jdselemane@gmail.com

5 Instituto Tecnológico Vale (ITV), Av. Juscelino Kubitscheck, Ouro Preto 35400-000, MG, Brazil; eunirio.zanetti@gmail.com

6 Department of Civil and Environmental, Universidad de la Costa, CUC, Calle 58 \# 55e66, Barranquilla 080002, Atlántico, Colombia; felipeqma@hotmail.com

* Correspondence: carlos.hoffmann@upc.edu

Received: 29 July 2020; Accepted: 30 August 2020; Published: 31 August 2020

\begin{abstract}
This paper proposes pre-beneficiation studies by air jigs of the coal layers from a Moatize coal deposit. Pre-beneficiation, also called destoning, removes tailings before the beneficiation plant. The air jigs operate in the same granulometric size range as the heavy-media cyclones (HMCs) that are installed in the preparation plant. With the destoning, the heavy-media circuit operates with a lower coal feed and higher organic matter contents, increasing its cutting efficiency and lowering operational costs. The use of air jigs reduces the total water consumption in the plant, which is especially important for the region where the plant is installed, as water is particularly scarce. Four coal layers of the Moatize coal deposit were studied, which are currently exploited in the mine. As main results of the study, it is possible to say that the concentration of lights (feed of the preparation plant) and heavies (waste fraction) in air jigs can be carried out with reasonable efficiencies for all coal layers studied, making air jigs a feasible option for coal destoning.
\end{abstract}

Keywords: air jig; destoning; waste separation; Moatize coal

\section{Introduction}

\subsection{Coal Basin and Coal Mine}

Steel is currently one of the main materials used in several industries worldwide. It is used in civil construction, the automotive industry, machinery in general, etc. In 2018, the world crude steel production was about 1870 million metric tons [1]. A large part of the steel produced worldwide comes from pig iron produced by the reduction of iron ore in blast furnaces. The reduction of iron ore, usually hematite $\left(\mathrm{Fe}_{2} \mathrm{O}_{3}\right)$, is accomplished by the coke used in blast furnaces. In 2018, about 640 million metric tons of coke [2] were produced for the metallurgical industry. Some coal 
that presents metallurgical properties can be used in blends to produce coke. Metallurgical coke is a macroporous carbon material of high strength produced by the carbonization of coals of specific rank or of coal blends at temperatures up to $1400 \mathrm{~K}$. They are used to maintain the process of iron production in the following main functions: (1) as a fuel, (2) as a chemical reducing agent, and (3) as permeable support [3]. There are not many metallurgical coal deposits in the world that can be used in coke production. One of these deposits is the Moatize deposit in Mozambique.

In Mozambique, the sedimentary basin, which created the coal deposits, was formed about 280 million years ago, during the so-called Karoo rifting, which affected the Eastern African Region. The Karoo coal basin, described as the Zambezi Basin and the Moatize Basin, extends over a distance of about $350 \mathrm{~km}$ and probably contains several billions of tons of coking coal reserves. This coal basin was considered one of the last explored coking coal basins in the world [4-7].

Ten different coal seams have been observed in the Moatize Basin [8], but six of them are the most important (Figure 1).

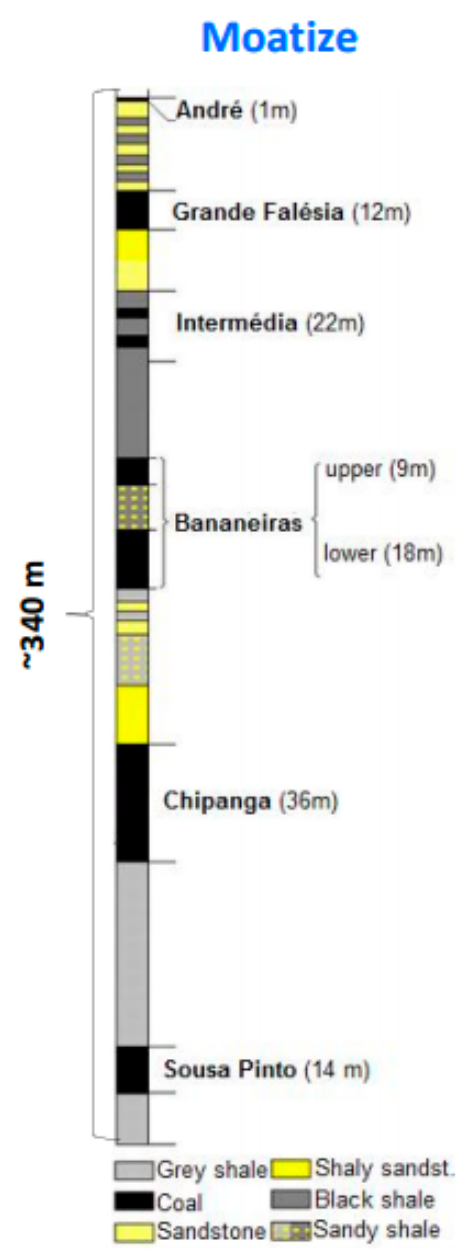

Figure 1. Moatize basin [8].

The Moatize mine in Mozambique, Tete Province, is a metallurgical coal mine that has been exploited by Vale S.A. since May 2011, when the mine was officially inaugurated. The estimated coal production is more than 22 million tons per annum (Mtpa) in an open-pit mine. The total estimated coal reserves are more than $2400 \mathrm{Mt}$ [9]. Due to the high demand for coking coal all over the world, coal production will increase sharply in the near future [9].

Chipanga is the coal seam exploited in the Moatize mine and presents around $30 \mathrm{~m}$ of thickness. The Chipanga seam is divided into 4 different layers, namely Upper Chipanga Top (UCT), Upper Chipanga Bottom (UCB), Middle-Low Chipanga Upper (MLCU), and LC456 (Low 
Chipanga LC), from the top to the bottom $[9,10]$. However, there are many small layers of shales and siltstones interlayered among the coal seams, increasing the contamination in the mining procedure. These materials greatly increase the waste that is mined and, consequently, they are crushed, sized, and beneficiated in a preparation plant.

In the mine, the run-of-mine (ROM) coal is crushed at a $50 \mathrm{~mm}$ top size and is sized in three fractions: $50 \mathrm{~mm} \times 1 \mathrm{~mm}$, coarse coal (yield 80\%-heavy media circuit); $1 \times 0.25 \mathrm{~mm}$ fine coal (yield $10 \%$-beneficiated in spirals or reflux equipment); and $-0.25 \mathrm{~mm}$ ultrafine coal (yield $10 \%$ - coal flotation). The coarse coal is processed in two heavy media cyclones (HMCs) in series. The sink coal, considered as final waste, presents more than $60 \%$ ash content and about $48 \%$ in mass of the ROM coal. These tailings can be partially removed in a destoning plant. With the destoning, the heavy media circuit operates with a lower coal feed and higher organic matter contents, increasing its cutting efficiency and lowering operational costs.

All mined coal is prepared using wet processes (flotation, spirals, reflux, and heavy media cyclones), which present high investment and operational costs. The use of heavy media concentration is especially expensive due to several factors, such as the installation of a parallel circuit to magnetite recovery, erosion produced by the magnetite particles, the associated higher operational costs, etc. Another important point is the expansion of the mine production. In the near future, coal production will increase significantly. If about $50 \%$ of the waste is removed before the material enters the preparation plant, mining production can be doubled without any change in the preparation plant.

The water used for the preparation plant is collected from an important African river called the Zambezi River. The river water is largely used for different purposes, especially for agriculture and domestic uses. There is a lack of water in all regions close to the coal deposit and the rational use of the Zambezi water is crucial for the region, the country, and the mine. If a dry process for destoning is installed and 50\% of the mined material's mass is removed, water use will be reduced to half, or with the same amount of water and preparation plant, double the amount of coal can be produced.

Regarding the coalification degree and taking into consideration the vitrinite reflectance mean value, the UCT and MLCU layers of the Moatize coal can be classified as a high-volatile bituminous coal (HVB-A), whereas the sublayers UCB and LC456 are of medium-volatile bituminous (MVB) type (ASTM).

\subsection{Coal Destoning}

Destoning, also known as pre-concentration, consists of the rejection of the high-density gangue from raw coal. It reduces the ash grade of the coal early in the beneficiation and avoids feeding the plant with unnecessary material. Furthermore, ROM destoning allows the processing of different mining blocks, potentially extending mine life by allowing the processing of smaller cut-off grades [11]. Due to their ability to handle coarse particles and high tonnages, gravity separation methods constitute the major option for destoning stages. Many dense media baths, such as the Drewboy, the Norwalt, and most of the drum separators, are extensively used for obtaining a pre-concentrate from raw coal [11]. However, despite their accuracy and precision, the high costs related to medium consumption, control of the medium density, and maintenance of several pumping circuits make dense media separation sometimes unattractive in comparison to cheaper methods, such as jigging.

Having a relatively high unity capacity and operational flexibility, jigging is a classical item used in the concentration of relatively coarse coal. Coal pre-concentration by jigging is traditionally carried out in hydraulic jigging devices, such as the Baum and Batac jigs [12]. However, with pressure to reduce water usage, old dry beneficiation technologies have been reconsidered while new techniques are starting to be developed.

In the last few years, dry concentration has played an important role in coal beneficiation, due to the increase in its separation efficiency, as well as the non-use of water $[13,14]$. Dry concentration in coal preparation has been used in the removal of clays and pyritic grains $[13,14]$. Dry concentration technologies of coal include air jigging [15-18], air dense medium fluidized beds [19-22], and most 
recently sensor-based sorting techniques $[11,23]$. Although the last example shows as a very promising option for pre-concentration stages, its application is still in the consolidation phase in the coal industry. In parallel, air tables and air dense medium fluidized beds are more suitable for processing intermediate or fine particle sizes and usually demand the preparation of a closely sized feed [24,25]. However, among all technologies available for the dry cleaning of coal, air jigging is favored due to its high unity capacity and ability to accept a large range in feed size [26,27]. Its application is suitable for pyrite removal and destoning of ROM coal, especially when the fraction of near-gravity material (NGM) is relatively low.

Jigging is an old concentration process used in mineral processing. It is based on the vertical pulsation of a particle through the movement of a fluid. Repeated expansions (dilatation) and contractions (compression) of the particle bed promote particle stratification. Air jigging was tested to remove high-density fractions containing elevated pyritic sulfur concentration from a low-rank coal [13], obtaining a reduction of sulfur content to $50 \%$ of the feed. The use of air jigging in destoning has been also published in several other works [16-18,26,27].

This article proposes a study of pre-beneficiation by air jig of the coal layers of Moatize. Pre-beneficiation, also called destoning, aims to remove part of the tailings and is installed before the beneficiation plant. Air jigs operate in the same granulometric range as the heavy media cyclones (HMCs) that are installed in the preparation plant. In this way, all the tailings removed by air jigs will not be treated by the HMCs, which have much higher operational costs. Thus, HMCs can work in a less overloaded manner, increasing their cutting efficiency and lowering operational costs.

\section{Materials and Methods}

\subsection{Coal Samples}

The samples used in this work were collected from the four coal layers that compose the Chipanga coal seam, named as follows: Upper Chipanga Top (UCT), Upper Chipanga Bottom (UCB), Middle-Low Chipanga Upper (MLCU), and LC456, here called Low Chipanga (LC). The samples were separately dried, crushed at a top size of $50 \mathrm{~mm}$, and sized in $50 \mathrm{~mm} \times 1 \mathrm{~mm}$ (same size range of the Moatize mine coarse coal circuit). The coarse particle samples were subsequently homogenized and riffled, and a mass of approximately $52 \mathrm{~kg}$ per sample was prepared to perform air jigging tests.

\subsection{Density Distribution Test}

For the density separation in sink-float tests, mixtures of the following heavy liquids were used: bromoform $\left(\mathrm{CHBr}_{3}\right.$; density $\left.2.89 \mathrm{~g} / \mathrm{cm}^{3}\right)$, perchloroethylene $\left(\mathrm{C}_{2} \mathrm{Cl}_{4}\right.$; density $\left.1.62 \mathrm{~g} / \mathrm{cm}^{3}\right)$, and xylene $\left(\mathrm{C}_{8} \mathrm{H}_{10}\right.$; density $\left.0.87 \mathrm{~g} / \mathrm{cm}^{3}\right)$. The initial coal samples in the size range of $50 \times 1 \mathrm{~mm}$ were submitted to sink-float tests in the densities of $1.5,1.6,1.7,1.8,1.9,2.0$, and $2.2 \mathrm{~g} / \mathrm{cm}^{3}$, according to ASTM D4371-06. The coal samples were so separated in the following density ranges: $\delta<1.5 \mathrm{~g} / \mathrm{cm}^{3}$, $1.5<\delta<1.6 \mathrm{~g} / \mathrm{cm}^{3}, 1.6<\delta<1.7 \mathrm{~g} / \mathrm{cm}^{3}, 1.7<\delta<1.8 \mathrm{~g} / \mathrm{cm}^{3}, 1.8<\delta<1.9 \mathrm{~g} / \mathrm{cm}^{3}, 1.9<\delta<2.0 \mathrm{~g} / \mathrm{cm}^{3}$, $2.0<\delta<2.2 \mathrm{~g} / \mathrm{cm}^{3}$, and $\delta>2.2 \mathrm{~g} / \mathrm{cm}^{3}$. All jigging products were also submitted to sink-float separation in the following density ranges: $\delta<1.6 \mathrm{~g} / \mathrm{cm}^{3}$ (here called lights), $1.6<\delta<2.2 \mathrm{~g} / \mathrm{cm}^{3}$ (here called middlings), and $\delta>2.2 \mathrm{~g} / \mathrm{cm}^{3}$ (here called heavies).

\subsection{Jigging Tests}

The jigging tests were carried out in a batch pilot-scale air jig model AllAir ${ }^{\circledR}$ S-500 (AllMineral Aufbereitungstechnik GmbH \& Co. KG, Düsseldorf, Germany) (Figure 2). During its operation, the bed pulsation caused by an upward pulsed airflow allows the segregation of particles of different densities and sizes, resulting from the differential vertical motion of the grains in response to the combined action of the gravity force (downward motion) and drag force (upward motion). The jigging chamber is assembled with different rectangular sections of plexiglass $(500 \mathrm{~mm} \times 500 \mathrm{~mm} \times 50 \mathrm{~mm})$, called here "Separation Sections" (Figure 2), fitted one over the other on a perforated plate $(\varnothing=1 \mathrm{~mm})$ for the 
upward airflow passage. The set of Separation Sections made possible the extraction of the particle beds layer by layer. The jig has a control panel in which it is possible to adjust the inlet air rate as a function of the percentage of the blower power $\left(15 \mathrm{~kW}\right.$, airflow up to $\left.73 \mathrm{~m}^{3} / \mathrm{min}\right)$, ranging from $0 \%$ to $100 \%$. The pulsation frequency can be set from 0 to 300 cycles per minute (CPM) by changing the rotation of the pneumatic flutter valve that controls the air inlet into the jig container. Four jigging tests were carried out, one for each of the four coal layers that compose the Chipanga coal seam (UCT, UCB, MLCU, and LC). Intake air rate, pulsation frequency, and jigging time were fixed at 80\% (approximately $60 \mathrm{~m}^{3} / \mathrm{min}$, estimated from the fan curve), $160 \mathrm{CPM}$, and $120 \mathrm{~s}$, respectively. These operating conditions were chosen based on previous studies with the same jig device [28].

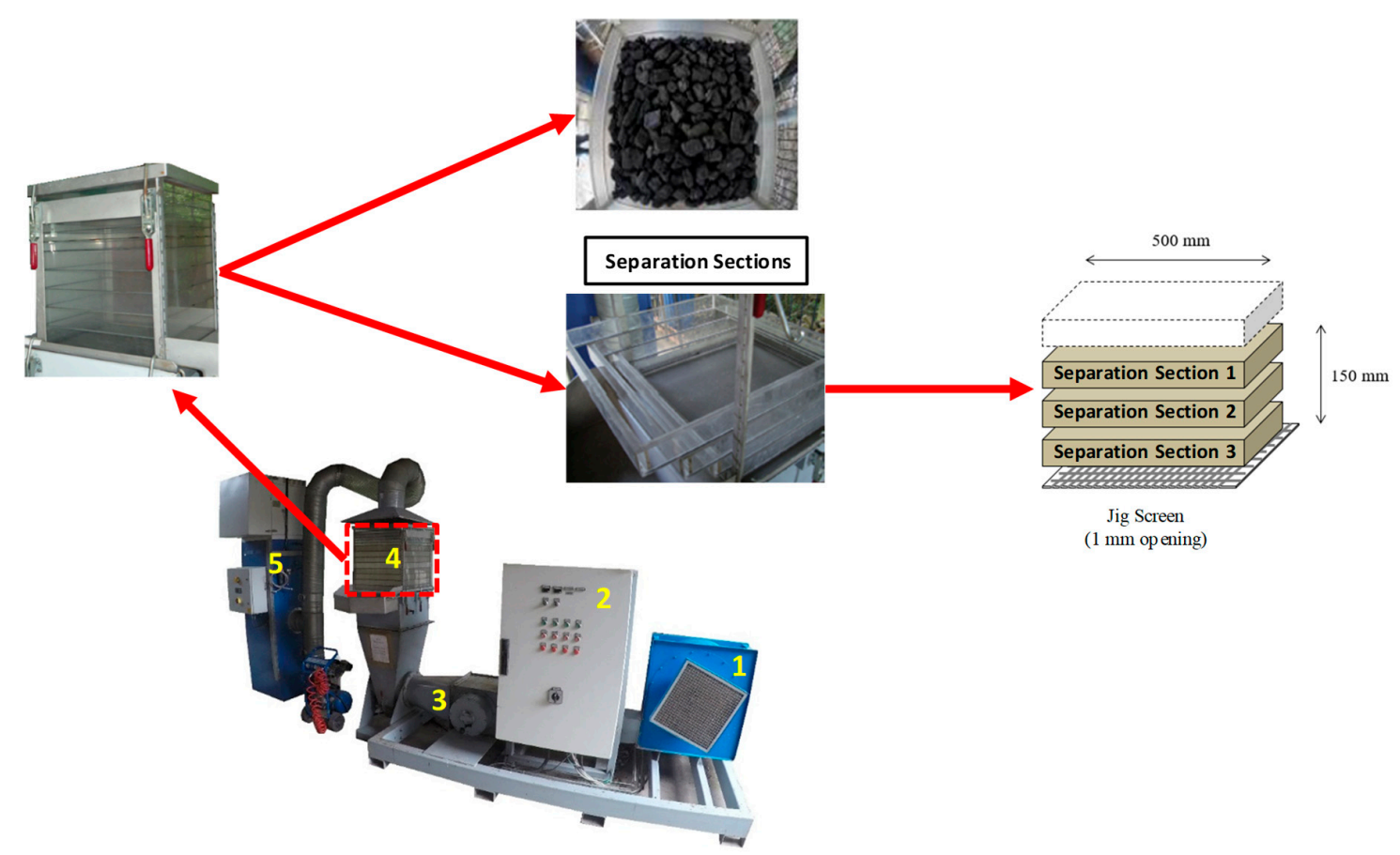

Figure 2. Air Jig AllMineral AllAir ${ }^{\circledR}$ S-500. The AllMineral Air Jig is composed of the following components: (1) blower; (2) control panel; (3) flutter valve; (4) jig container; (5) dust collection hopper.

The coal amount used for each jigging test was about $52 \mathrm{~kg}$, providing enough volume to fill the three Separation Sections (Figure 2). After jigging, each of the 3 Separation Sections was removed individually as follows: Separation Section 1 (S1), in the top stratum, containing mainly the light coal particles; Separation Section 2 (S2), in the middle stratum containing mainly coals of intermediate densities; and Separation Section 3 (S3), in the bottom stratum containing mainly the denser coal particles (Figure 2). Each fraction was individually riffled to produce a representative sample of $3 \mathrm{~kg}$, which was subsequently submitted to sink-float tests.

\section{Results and Discussion}

\subsection{Size Distribution}

Table 1 presents the size distribution of the four coal layers (UCT, UCB, MLCU, and LC) of the Moatize coal seam. Three coal layers, i.e., UCT, UCB, and MLCU, presented masses of around $80 \%$ in the size fraction of $50 \mathrm{~mm} \times 1 \mathrm{~mm}$ (jigging feed), whereas the LC coal layer presented a mass of about $70 \%$. If a coal destoning is installed, about $80 \%$ of the ROM coal will be prepared in this installation. This year, namely 2020, a production of 30 million tons of ROM coal is expected. This represents about 12 million tons of wastes that can be separated in a future destoning plant. 
Table 1. Size distribution in mass (wt\%) of the coal layers (UCT, UCB, MLCU, and LC).

\begin{tabular}{cccc}
\hline \multicolumn{3}{c}{ Size Range } \\
\hline Coal Seam & $\mathbf{5 0} \mathbf{~} \mathbf{m} \times \mathbf{1} \mathbf{~ m m}$ & $<\mathbf{~} \mathbf{~ m m}$ & Total \\
\hline UCT & 79.12 & 20.88 & 100 \\
UCB & 79.11 & 20.89 & 100 \\
MLCU & 81.74 & 18.26 & 100 \\
LC & 68.74 & 31.26 & 100 \\
\hline
\end{tabular}

\subsection{Density Distribution}

Figure 3 presents the washability curves (Henry-Reinhardt Curves) of the four coal layers of the Moatize coal seam. It is important to emphasize that typical Henry-Reinhardt curves present only three curves (density curve, float curve, and sink curve). The near-gravity material (NGM) curve is derived from the density curve. It represents the percentage $(w \mathrm{t} \%)$ of the coal that lies within $\pm 0.1 \mathrm{~g} / \mathrm{cm}^{3}$ at any cut density and indicates the ease of separation by density at a given cut density (the higher the NGM value, the more difficult is the separation by density).
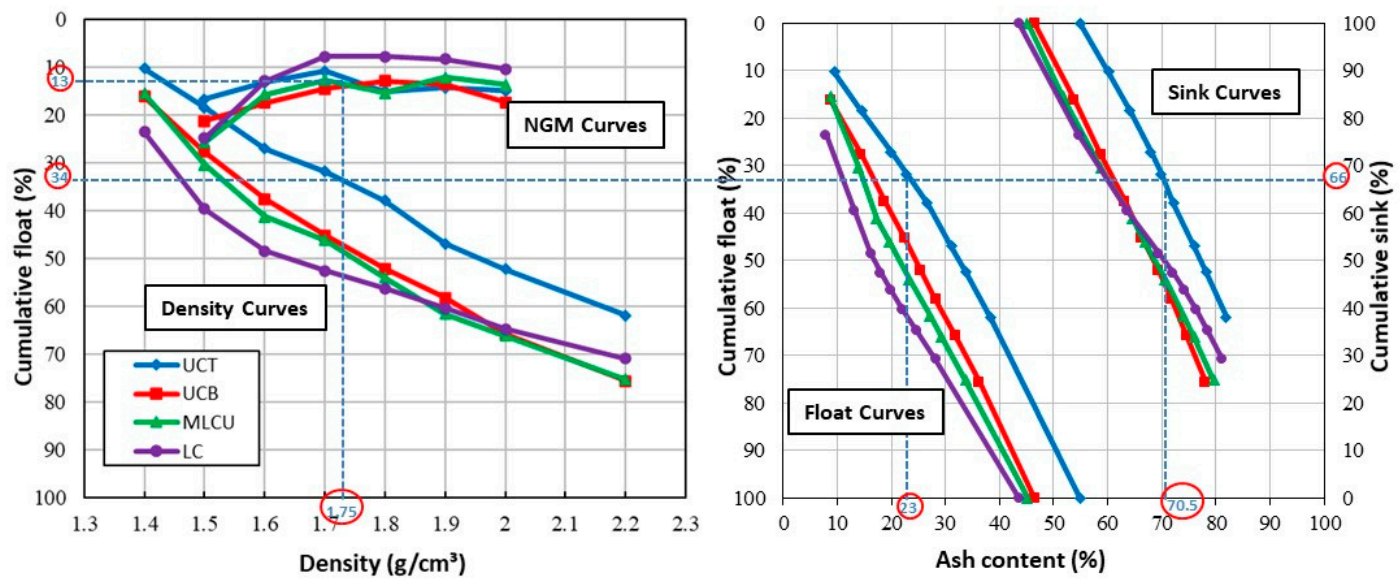

Figure 3. Washability curves (Henry-Reinhardt curves) of the Moatize coal layers (UCT, UCB, MLCU, and LC).

To illustrate the usage of the curves, the following example can be seen in Figure 3 for the UCT coal layer (blue in the figure). The cumulative coal density of the coal particles is expressed by the density curve. It is observed that $34 \%$ of the coal particles have a density lower than $1.75 \mathrm{~g} / \mathrm{cm}^{3}$ and, consequently, $66 \%$ have a density over $1.75 \mathrm{~g} / \mathrm{cm}^{3}$. The float curve presents the cumulative float ash content. Thus, the coal with a density lower than $1.75 \mathrm{~g} / \mathrm{cm}^{3}$ (34\% in mass) presents $23 \%$ ash content (float curve). In contrast, the sink curve presents the cumulative sink ash content; the coal with a density higher than $1.75 \mathrm{~g} / \mathrm{cm}^{3}$ (66\% in mass) presents $70.5 \%$ ash content. The NGM curve expresses the amount of mass with $\pm 0.1 \mathrm{~g} / \mathrm{cm}^{3}$ of the separation density $\left(1.75 \mathrm{~g} / \mathrm{cm}^{3}\right)$. In this case, by the separation at density $1.75 \mathrm{~g} / \mathrm{cm}^{3}, 13 \%$ of particles (in mass) are in the density range of 1.65 to $1.85 \mathrm{~g} / \mathrm{cm}^{3}$. Such particles have almost similar probabilities to be directed either to the lighter or the denser fraction, thereby contributing to the separation imperfection.

The Henry-Reinhardt curves are largely used for coal characterization, providing information about the theoretical mass recoveries, ash content, and NGM at any cut density. It should be noted, however, that the curves depend on the coal size range, which is intimately linked to the organic matter liberation, and affect the coal density distribution. Figure 3 shows clearly the lowest coal mass recovery (see the float curves) of the UCT coal layer in comparison to the other coal layers. For any cut density, the UCT layer presents a lower amount of float material. It is also possible to see that the coal layers present NGM around 15\% for the UCT, UCB, and MLCU coal layers and around $10 \%$ for the 
LC coal layer in all cut densities over $1.6 \mathrm{~g} / \mathrm{cm}^{3}$. Separations with NGM around $15 \%$ are considered "Moderately Difficult" and 10\% "Relatively Simple" [29].

An important characteristic presented by this coal is a large amount of dense material presented in all coal layers (Figure 3). The UCB, MLCU, and LC coal layers present about $25 / 30 \%$, and the UCT coal layer about $40 \%$, of material with a density over $2.2 \mathrm{~g} / \mathrm{cm}^{3}$ (considered waste in this work). The ash content of the coals in density higher than $2.2 \mathrm{~g} / \mathrm{cm}^{3}$ is around $80 \%$. Based on the washability curves, it is theoretically possible to remove between $30 \%$ and $40 \%$ in mass of high-ash content material before the feeding of the heavy media plant. Consequently, the amount of material to be processed in the preparation plant would be considerably lower if it were constituted by pre-concentrated material (i.e., with lower ash contents). The installed coal preparation plant presents a density cut in the first HMC of $1.5 \mathrm{~g} / \mathrm{cm}^{3}$. All material with a density over $1.5 \mathrm{~g} / \mathrm{cm}^{3}$ is considered waste. In a perfect cut, based on the washability curves, there is at least $60 \%$ of waste (density over $1.5 \mathrm{~g} / \mathrm{cm}^{3}$ ) for the LC coal layer and at most $80 \%$ for the UCT coal layer. It should be emphasized that the recoveries of these masses in the waste material do not take into consideration the cut imperfection of the equipment, but a large amount of mass can be separated as waste in this coal.

\subsection{Sulfur Distribution}

Table 2 presents the total sulfur content of the coal layers of the Moatize coal seam. In general, the coal layers present low total sulfur content, with contents under $1 \%$ in almost all density fractions.

Table 2. Total sulfur content ( $w \mathrm{t} \%$ ) in different density ranges for the UCT, UCB, MLCU, and LC coal layers.

\begin{tabular}{ccccc}
\hline \multirow{2}{*}{$\begin{array}{c}\text { Density (8) Range } \\
\left(\mathbf{g} / \mathbf{c m}^{3}\right)\end{array}$} & \multicolumn{4}{c}{ Sulfur Content (weight \%) } \\
\cline { 2 - 5 } & UCT & UCB & MLCU & LC \\
\hline$\delta<1.4$ & 0.9 & 0.9 & 0.5 & 0.5 \\
$1.4<\delta<1.5$ & 1.0 & 0.8 & 0.6 & 0.6 \\
$1.5<\delta<1.6$ & 0.9 & 0.7 & 0.6 & 0.6 \\
$1.6<\delta<1.7$ & 0.7 & 0.6 & 0.5 & 0.5 \\
$1.7<\delta<1.8$ & 0.8 & 0.6 & 0.6 & 0.6 \\
$1.8<\delta<1.9$ & 0.5 & 0.6 & 0.4 & 0.4 \\
$1.9<\delta<2.0$ & 0.5 & 0.3 & 0.5 & 0.5 \\
$2.0<\delta<2.2$ & 0.9 & 0.3 & 1.1 & 1.1 \\
$\Delta>2.2$ & 0.8 & 0.6 & 0.5 & 0.5 \\
\hline
\end{tabular}

The total sulfur content presents higher values for lower and for higher density fractions. The lowest contents are presented in middle densities. The higher total sulfur contents in lighter density fractions are related to organic sulfur [10], which are linked to the organic matter. The larger is the amount of organic matter in the density fraction (lower densities), whereas the higher is the organic sulfur content. The total sulfur content presents also higher values for denser particles, due to the pyrite grains presented in these density fractions [10]. In a future destoning plant, the product feeding the HMC will present the same sulfur content or a little higher, since the total sulfur is related to organic sulfur.

\subsection{Stratification Profiles}

Table 3 presents material masses in three density fractions $\left(\delta<1.6 \mathrm{~g} / \mathrm{cm}^{3}, 1.6<\delta<2.2 \mathrm{~g} / \mathrm{cm}^{3}\right.$, and $\delta>2.2 \mathrm{~g} / \mathrm{cm}^{3}$ ) directed to the three Separation Sections (see Figure 2) after jigging, for the four coal layers. Mass recoveries are presented and discussed below. To clarify the table, it is possible to observe that Separation Section 1 of the MLCU layer presents $64.8 \%$ in mass of lights $\left(\delta<1.6 \mathrm{~g} / \mathrm{cm}^{3}\right), 33.3 \%$ of middlings $\left(1.6<\delta<2.2 \mathrm{~g} / \mathrm{cm}^{3}\right)$, and $1.9 \%$ of heavies $\left(\delta>2.2 \mathrm{~g} / \mathrm{cm}^{3}\right)$. 
Table 3. Masses (wt $\%$ ) in densities fraction $\left(\delta<1.6 \mathrm{~g} / \mathrm{cm}^{3}, 1.6<\delta<2.2 \mathrm{~g} / \mathrm{cm}^{3}\right.$, and $\delta>2.2 \mathrm{~g} / \mathrm{cm}^{3}$ ) directed to the three Separation Sections after jigging, for the four coal layers.

\begin{tabular}{|c|c|c|c|c|c|}
\hline & & $\delta<1.6 \mathrm{~g} / \mathrm{cm}^{3}$ & $\begin{array}{c}\text { Density Range } \\
1.6<\delta<2.2 \mathrm{~g} / \mathrm{cm}^{3}\end{array}$ & $\delta>2.2 \mathrm{~g} / \mathrm{cm}^{3}$ & Total \\
\hline & & Mass (wt\%) & Mass (wt\%) & Mass (wt\%) & \\
\hline \multirow{3}{*}{$\begin{array}{c}\text { Coal } \\
\text { Layer-UCT }\end{array}$} & Sep. Section 1 (S1) & 18.4 & 69.1 & 12.5 & 100 \\
\hline & Sep. Section 2 (S2) & 12.2 & 32.3 & 55.5 & 100 \\
\hline & Sep. Section 3 (S3) & 0.0 & 40.6 & 59.4 & 100 \\
\hline \multirow{3}{*}{$\begin{array}{c}\text { Coal } \\
\text { Layer-MLCU }\end{array}$} & Sep. Section 1 (S1) & 64.8 & 33.3 & 1.9 & 100 \\
\hline & Sep. Section 2 (S2) & 26.6 & 58.3 & 15.1 & 100 \\
\hline & Sep. Section 3 (S3) & 12.0 & 53.9 & 34.1 & 100 \\
\hline \multirow{3}{*}{$\begin{array}{c}\text { Coal } \\
\text { Layer-LC }\end{array}$} & Sep. Section 1 (S1) & 85.4 & 14.6 & 0.0 & 100 \\
\hline & Sep. Section 2 (S2) & 29.7 & 55.4 & 14.9 & 100 \\
\hline & Sep. Section 3 (S3) & 9.0 & 24.9 & 66.1 & 100 \\
\hline \multirow{3}{*}{$\begin{array}{c}\text { Coal } \\
\text { Layer-UCB }\end{array}$} & Sep. Section 1 (S1) & 53.3 & 42.3 & 4.4 & 100 \\
\hline & Sep. Section 2 (S2) & 22.3 & 66.5 & 11.2 & 100 \\
\hline & Sep. Section 3 (S3) & 7.8 & 43.2 & 49.0 & 100 \\
\hline
\end{tabular}

In general, most of the lights $\left(\delta<1.6 \mathrm{~g} / \mathrm{cm}^{3}\right)$ were concentrated in S1 (Separation Section 1, top layer, see Figure 2), whereas the heavies $\left(\delta>2.2 \mathrm{~g} / \mathrm{cm}^{3}\right)$ were preferentially concentrated in S3 (bottom layer). On the contrary, the middlings $\left(1.6<\delta<2.2 \mathrm{~g} / \mathrm{cm}^{3}\right)$ lie relatively dispersed over the layers.

In a perfect jigging stratification, S1 should contain all lights $\left(\delta<1.6 \mathrm{~g} / \mathrm{cm}^{3}\right)$ and $\mathrm{S} 3$ all heavies $\left(\delta>2.2 \mathrm{~g} / \mathrm{cm}^{3}\right)$. It is certain that both separation sections would be contaminated with middlings $\left(1.6<\delta<2.2 \mathrm{~g} / \mathrm{cm}^{3}\right)$ due to the lights, and the heavies do not have enough mass to completely fill S1 and S3. Mass recoveries are presented and discussed below.

As mentioned, the washability curves (Figure 3) present the lowest NGM values for the LC coal layer, indicating that this coal layer is the easiest to be concentrated. As can be seen from Table 3, this coal layer presents the highest product purity-S1 presents $85.4 \%$ of lights (highest value) and S3 presents $66.2 \%$ of heavies (highest value). As mentioned, air jigging presents lower efficiencies in comparison with water jigs and especially heavy media processes, but in a destoning circuit, the main purpose is the removal of waste material. In this case, the cut density should be high enough to avoid, as much as possible, losses in the destoning pre-concentrate. This means the plant should ensure that most of the light material to be recovered in the HMCs will be in the pre-concentrate and that most of the wastes will be removed.

In general, it is possible to say that the concentration of lights in S1 and the concentration of heavies in S3 occurred with reasonable efficiency for all coal layers. The low amount of lights (18.4\%) in Separation Section 1 of the UCT layer is more related to the low amount of lights in the jigging feed (see Figure 3, the lowest amount of particles in density lower than $1.6 \mathrm{~g} / \mathrm{cm}^{3}$ ) than to the jigging efficiency. This statement is discussed below.

It is possible to see in Table 4 the density distribution in each Separation Section (see Figure 2) in terms of mass recoveries of each density range for the four coal layers. 
Table 4. Mass recoveries in each density fraction $\left(\delta<1.6 \mathrm{~g} / \mathrm{cm}^{3}, 1.6<\delta<2.2 \mathrm{~g} / \mathrm{cm}^{3}\right.$, and $\left.\delta>2.2 \mathrm{~g} / \mathrm{cm}^{3}\right)$ reported to the three Separation Sections after jigging, for the four coal layers.

\begin{tabular}{|c|c|c|c|c|}
\hline & & $\delta<1.6 \mathrm{~g} / \mathrm{cm}^{3}$ & $\begin{array}{c}\text { Density Range } \\
1.6<\delta<2.2 \mathrm{~g} / \mathrm{cm}^{3}\end{array}$ & $\delta>2.2 \mathrm{~g} / \mathrm{cm}^{3}$ \\
\hline & & Mass (wt $\%)$ & Mass (wt\%) & Mass (wt $\%)$ \\
\hline \multirow{4}{*}{ Coal Layer-UCT } & Sep. Section 1 (S1) & 60.1 & 48.5 & 9.8 \\
\hline & Sep. Section 2 (S2) & 39.9 & 22.8 & 43.6 \\
\hline & Sep. Section 3 (S3) & 0.0 & 28.7 & 46.6 \\
\hline & Total & 100 & 100 & 100 \\
\hline \multirow{4}{*}{$\begin{array}{c}\text { Coal } \\
\text { Layer-MLCU }\end{array}$} & Sep. Section 1 (S1) & 62.7 & 22.9 & 3.7 \\
\hline & Sep. Section 2 (S2) & 25.7 & 40.0 & 29.6 \\
\hline & Sep. Section 3 (S3) & 11.6 & 37.1 & 66.7 \\
\hline & Total & 100 & 100 & 100 \\
\hline \multirow{4}{*}{ Coal Layer-LC } & Sep. Section 1 (S1) & 68.9 & 15.5 & 0.0 \\
\hline & Sep. Section 2 (S2) & 23.9 & 58.2 & 18.3 \\
\hline & Sep. Section 3 (S3) & 7.2 & 26.3 & 81.7 \\
\hline & Total & 100 & 100 & 100 \\
\hline \multirow{4}{*}{ Coal Layer-UCB } & Sep. Section 1 (S1) & 63.9 & 27.8 & 6.8 \\
\hline & Sep. Section 2 (S2) & 26.8 & 43.8 & 17.4 \\
\hline & Sep. Section 3 (S3) & 9.3 & 28.4 & 75.8 \\
\hline & Total & 100 & 100 & 100 \\
\hline
\end{tabular}

It is possible to see in Table 4 that most of the lights were concentrated in S1, i.e., UCT $60.1 \%$, UCB $63.8 \%$, MLCU $62.7 \%$, and LC $68.9 \%$, and that most of the heavies were directed to S3, i.e., UCT $46.6 \%$, UCB $75.8 \%$, MLCU $66.7 \%$, and LC $81.7 \%$.

It can be observed that the LC coal layer presents the highest mass recovery for the lights in S1 and the heavies in S3. The tendency confirms the results presented in Table 4.

The coal layer with the lowest coal mass recovery according to Table 4 is UCT. This coal layer presented the lowest mass recovery of the lights and the heavies in S1 and S3, respectively.

In general, it can be assumed that it is possible to separate considerable masses of wastes in S3 without significant losses of coal (especially for the UCT layer), thus making coal destoning possible using air jigs.

\subsection{Destoning Considerations}

Table 5 presents the mass balance of the washability curves, coal layers, and jigging tests. The two columns under the washability curves in Table 5 express the masses of material with a density over $2.2 \mathrm{~g} / \mathrm{cm}^{3}$ and their respective ash contents extracted from the washability curves (Figure 3). The results also present the theoretical recoveries of the masses. The two columns of the "Coal Layers" express the coal mass in each coal layer of the Moatize coal seam. The columns under "Jigging Tests" present the wastes (heavies, $\delta>2.2 \mathrm{~g} / \mathrm{cm}^{3}$ ) in S3, the amount of wastes related to the washability curves (mass of heavies in the washability curves plus the mass of heavies in S3), and the mass of wastes related to the coal layers. For instance, UCT presents $38.10 \%$ in mass and $81.90 \%$ ash content of wastes (heavies, $\delta>2.2 \mathrm{~g} / \mathrm{cm}^{3}$ ) in the washability curves; UCT represents $13.92 \%$ in mass of the Moatize coal seam; and UCT, after jigging tests, presents $2.47 \%$ in mass of the wastes, which are in the original coal layer in the Moatize coal seam. This means that $2.47 \%$ of the total coal layers (Moatize seam) can be removed as waste in S3. In total, $18.23 \%$ in mass of the Moatize coal seam can be removed as waste in S3. The mass balance indicates that up to $18.23 \%$ of the Moatize coal seam (i.e., including all the four layers) could be removed as waste in a single destoning stage by using dry jigging. This mass balance is related to the coarse particles' $(50 \mathrm{~mm} \times 1 \mathrm{~mm}$ ) mass and is represented in Figure 4. 
Table 5. Mass balance of the washability curves, coal layers, and of the jigging tests.

\begin{tabular}{|c|c|c|c|c|c|c|c|}
\hline \multirow{3}{*}{ Coal Layer } & \multicolumn{2}{|c|}{ Washability Curves } & \multicolumn{2}{|c|}{ Coal Layers } & \multicolumn{3}{|c|}{ Jigging Tests } \\
\hline & Mat $\delta>2.2 \mathrm{~g} / \mathrm{cm}^{3}$ & Ash Content & Layer Thickness & Mass in Seam & Mat $\delta>2.2 \mathrm{~g} / \mathrm{cm}^{3}$ & Mat $\delta>2.2 \mathrm{~g} / \mathrm{cm}^{3}$ & Mat $\delta>2.2 \mathrm{~g} / \mathrm{cm}^{3}$ \\
\hline & $(w t \%)$ & $(w t \%)$ & (m) & $(w t \%)$ & $(w t \%)$ & Relat. Sink-Float & Relat. Coal Layer \\
\hline UCT & 38.10 & 81.90 & 4.08 & 13.92 & 46.60 & 17.75 & 2.47 \\
\hline UCB & 24.40 & 78.04 & 11.80 & 40.25 & 75.80 & 18.50 & 7.44 \\
\hline MLCU & 24.75 & 79.59 & 10.44 & 35.61 & 66.70 & 16.51 & 5.88 \\
\hline LC & 29.13 & 81.13 & 3.00 & 19.23 & 81.70 & 23.80 & 2.44 \\
\hline Total & & & 29.32 & 100.00 & & & 18.23 \\
\hline
\end{tabular}




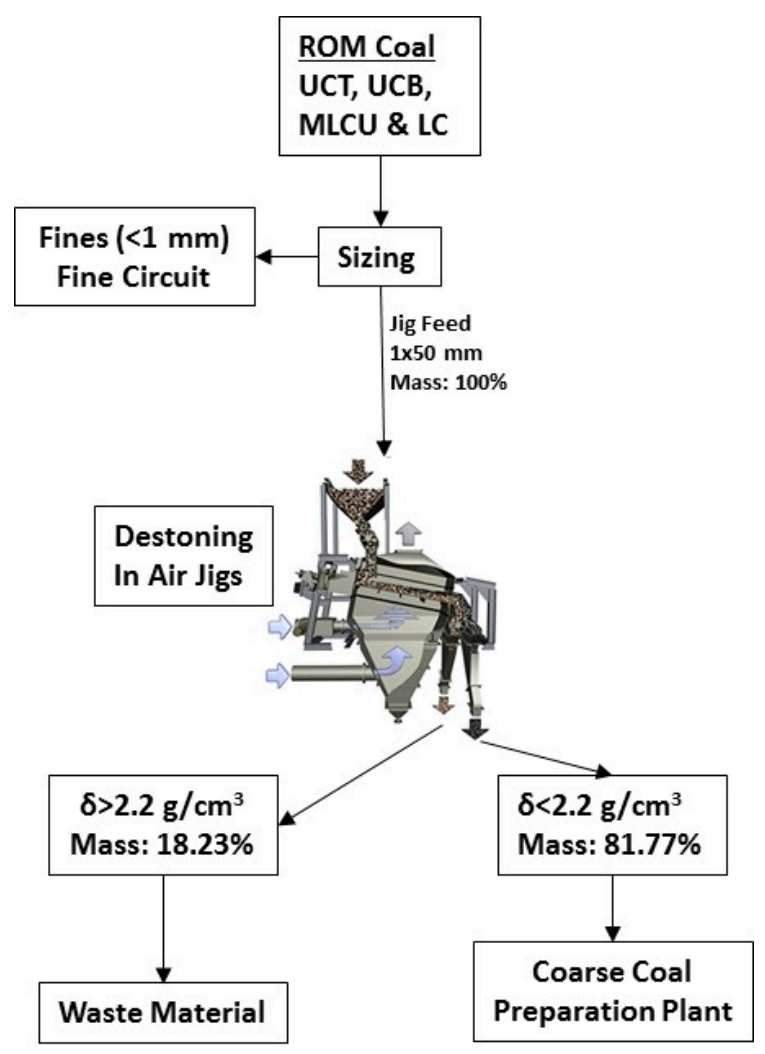

Figure 4. Flowsheet of the destoning circuit and the approximate mass balance.

Figure 4 presents a flowsheet of the air jigging circuit and the approximate mass balance of the coarse particles ( $50 \mathrm{~mm} \times 1 \mathrm{~mm}$ ), based on Tables 1 and 5 .

Figure 4 summarizes the destoning mass balance of this work. It is possible to remove about $18 \%$ in mass of all heavies $\left(\delta>2.2 \mathrm{~g} / \mathrm{cm}^{3}\right)$ of the Moatize coal seam in the size range of 50 to $1 \mathrm{~mm}$. It is certain that the sink product of a continuous jigging process will present more than $18 \%$ in mass, due to the presence of some middlings and lights. These materials are related to the jigging cut imperfection based on the Tromp distribution. All tests carried out in this work used Separation Sections with pre-defined size (50 $\mathrm{mm}$ high). The amount of lights and middlings in these sections depends on the factors discussed above (Tables 3 and 4 ).

The pre-concentrated coal $\left(\delta<2.2 \mathrm{~g} / \mathrm{cm}^{3}\right)$ with about $80 \%$ of the coarse particles $(20 \%$ removed in air jigs) goes to the coarse coal preparation plant, which produces low-density coals (coking and thermal coals). This plant uses heavy media cyclones in coal production, with much higher operational costs than air jigs. In this case, destoned coal feeds the preparation plant with $20 \%$ less material (heavy particles discharged in air jigs). A higher number of coarse particles can feed the circuit since $20 \%$ is removed before the preparation plant or a smaller plant can be used (part of the equipment can be deactivated). A better cut efficiency is also expected in the heavy media, due to the lower density of the coal. Another advantage is a lower deterioration of the plant since the denser particles with pyrite grains are removed.

\section{Conclusions}

The main conclusions of the paper can be summarized as follows: sink-float results showed a significant difference in the coal mass recovery profiles from distinct layers; the LC coal layer presents about $10 \%$ NGM in the coal densities over $1.6 \mathrm{~g} / \mathrm{cm}^{3}$; the coal layers present from $25 \%$ to $40 \%$ of the material with density higher than $2.2 \mathrm{~g} / \mathrm{cm}^{3}$ (waste fraction), ash contents around $80 \%$, and total sulfur contents lower than $1 \%$ in almost all density fractions; and in an industrial destoning jigging plant, it is 
expected that about $18 \%$ of all heavies $\left(\delta>2.2 \mathrm{~g} / \mathrm{cm}^{3}\right)$ of the Moatize coal seam in the size range of 50 to $1 \mathrm{~mm}$ will be removed.

Author Contributions: Conceptualization: C.H.S., W.M.A. and D.S.J.; Methodology: B.C., J.O.M., G.L.M., I.A.S.d.B. and C.O.P.; Validation: E.Z.F. and L.F.S.O.; Writing: C.H.S. and L.F.S.O. All authors have read and agreed to the published version of the manuscript.

Funding: This research was funded by Instituto Tecnológico Vale (ITV) Ouro Preto, Brazil.

Acknowledgments: The authors would like to thank the Instituto Tecnológico Vale (ITV), Ouro Preto, Brazil, for the coal samples. Carlos Hoffmann Sampaio is a Serra Húnter Fellow.

Conflicts of Interest: The authors declare no conflict of interest.

\section{References}

1. Statista. Global Coke Production 1993 to 2018 (in Million Metric Tons). Available online: https://www.statista. com/statistics/267891/global-coke-production-since-1993 (accessed on 27 July 2020).

2. Statista. World Crude Steel Production from 2012 to 2019 (in Million Metric Tons). Available online: https://www.statista.com/statistics/267264/world-crude-steel-production/ (accessed on 27 July 2020).

3. Díez, M.A.; Alvarez, R.; Barriocanal, C. Coal for metallurgical coke production: Predictions of coke quality and future requirements for cokemaking. Int. J. Coal Geol. 2002, 50, 389-412. [CrossRef]

4. Hatton, W.; Fardell, A. New discoveries of coal in Mozambique: Development of the coal resource estimation methodology for International Resource Reporting Standards. Int. J. Coal Geol. 2012, 89, 2-12. [CrossRef]

5. Vasconcelos, L.; Muchangos, A.; Siquela, E. Elementos traços em cinzas de carvões aflorantes de Moçambique. Geochim. Bras. 2009, 23, 344-361.

6. Cairncross, B. An overview of the Permian (Karoo) coal deposits of southern Africa. Afr. Earth Sci. 2001, 33, 529-562. [CrossRef]

7. Lakshminarayana, G. Geology of Barcode type coking coal seams, Mecondezi sub-basin, Moatize Coalfield, Mozambique. Int. J. Coal Geol. 2015, 146, 1-13. [CrossRef]

8. Vasconcelos, L. Geologia do Carvão: Caracterização geológica da Bacia de Moatize-Moçambique; UEM Universidade Eduardo Mondlane: Maputo, Mozambique, 2005. (In Portuguese)

9. Vale. 2018. Available online: http://www.vale.com/mozambique/PT/business/mining/coal/moatize-coalmine/Paginas/default.aspx (accessed on 10 November 2018).

10. José, D.S. Caracterização Tecnológica de Carvão ROM da Mina de Moatize-Moçambique Para o "Destoning”, Visando Seu Beneficiamento. Ph.D. Thesis, Universidade Federal do Rio Grande do Sul, Porto Alegre, Brazil, 2018; p. 223. (In Portuguese)

11. Wills, B.A.; Finch, J.A. Mineral Processing Technology: An Introduction to the Practical Aspects of Ore Treatment and Mineral Recovery, 8th ed.; Butterworth-Heinemann: Oxford, UK, 2016.

12. Charan, G.T.; Chattopadhyay, U.S.; Singh, K.M.P.; Kabiraj, S.; Haldar, D.D. Pilot-Scale Baum Jig Washing for Beneficiation of a High-Ash Indian Non coking Coal. Int. J. Coal Prep. Util. 2009, 29, 130-139. [CrossRef]

13. Dwari, R.K.; Rao, K.H. Dry beneficiation of coal-A review. Miner. Process. Extr. Metall. Rev. 2007, 28, 177-234. [CrossRef]

14. Xia, W.; Xie, G.; Peng, Y. Recent advances in beneficiation for low rank coals. Powder Technol. 2015, 277, 206-221. [CrossRef]

15. Sampaio, C.H.; Aliaga, W.; Pacheco, E.T.; Petter, E.; Wotruba, H. Coal beneficiation of Candiota mine by dry jigging. Fuel Process. Technol. 2008, 89, 198-202. [CrossRef]

16. Boylu, F.; Talı, E.; Çetinel, T.; Çelik, M.S. Effect of fluidizing characteristics on upgrading of lignitic coals in gravity based air jig. Int. J. Miner. Process. 2014, 129, 27-35. [CrossRef]

17. Charan, T.G.; Chattopadhyay, U.S.; Singh, K.M.P.; Kabiraj, S.K.; Haldar, D.D. Beneficiation of high-ash, Indian non-coking coal by dry jigging. Min. Metall. Explor. 2011, 28, 21-23.

18. Boylu, F.; Çinku, K.; Çetinel, T.; Karakaş, F.; Güven, O.; Karaağaçlioğlu, I.E.; Çelik, M.S. Effect of coal moisture on the treatment of a lignitic coal through a semi-pilot-scale pneumatic stratification jig. Int. J. Coal Prep. Util. 2015, 35, 143-154. [CrossRef]

19. Ihedioha, J.I.; Okorie-kanu, C.O.; Iwuogo, U.M. Upgrading coal using a pneumatic density based separator. Int. J. Coal Prep. Util. 2008, 28, 51-67. 
20. Zhao, Y.; Fu, Z.; Yang, L.Z.; Duan, C.; Song, S.; Cai, L. Fine Coal Dry Cleaning using an Air Dense Medium Fluidized Bed with Improved Magnetite Medium. Procedia Eng. 2015, 102, 1133-1141. [CrossRef]

21. Fu, Z.; Zhao, Y.; Yang, X.; Luo, Z.; Zhao, J. Fine coal beneficiation via air-dense medium fluidized beds with improved magnetite powders. Int. J. Coal Prep. Util. 2016, 36, 55-68. [CrossRef]

22. Xu, X.; Chen, J.; Luo, Z.; Tang, L.; Zhao, Y.; Lv, B.; Fu, Y.; Chen, C. Fluidization Characteristics of Air Dense Medium Agitated Separation Fluidized Bed with Different Distributors. Miner. Process. Extr. Metall. Rev. 2019, 40, 299-306. [CrossRef]

23. Nienhaus, K.; Pretz, T.; Wotruba, H. Sensor Technologies: Impulses for the Raw Materials Industry; Shaker Verlag GmbH: Düren, Germany, 2014; p. 476.

24. Duan, C.-L.; He, Y.-Q.; Zhao, Y.-M.; He, J.-F.; Wen, B.F. Development and application of the active pulsing air classification. Proceed Earth Planet. Sci. 2009, 1, 667-672.

25. Das, A.; Sarkar, B. Advanced gravity concentration of fine particles: A review. Miner. Process.Extr. Metall. Rev. 2018, 39, 359-394. [CrossRef]

26. Weinstein, R.; Snoby, R. Advances in dry jigging improves coal quality. Min. Eng. 2007, 1, $29-34$.

27. Snoby, R.; Thompson, K.; Mishra, S.; Snoby, B. Dry jigging coal: Case history performance. In Proceedings of the 2009 SME Annual Meeting, Denver, CO, USA, 22-25 February 2009.

28. Ambrós, W.M.; Sampaio, C.H.; Cazacliu, B.G.; Conceição, P.N.; Reis, G.S. Some observations on the influence of particle size and size distribution on stratification in pneumatic jigs. Powder Technol. 2019, 342, 594-606. [CrossRef]

29. Bird, B.M. Interpretation of float-and-sink data, Anais, II. Int. Conf. Bitum. Coal 1928, 2, 82-111.

(C) 2020 by the authors. Licensee MDPI, Basel, Switzerland. This article is an open access article distributed under the terms and conditions of the Creative Commons Attribution (CC BY) license (http://creativecommons.org/licenses/by/4.0/). 